\title{
Pencak Silat Talent Test Development
}

\author{
Rony Syaifullah $^{1, *}$, Rumi Iqbal Doewes ${ }^{2}$ \\ ${ }^{1}$ Department of Physical, Health, and Recreational Education, Faculty of Sport, Sebelas Maret University, Indonesia \\ ${ }^{2}$ Department of Sport Coaching Education, Faculty of Sport, Sebelas Maret University, Indonesia
}

Received August 13, 2020; Revised November 9, 2020; Accepted November 19, 2020

\section{Cite This Paper in the following Citation Styles}

(a): [1] Rony Syaifullah, Rumi Iqbal Doewes , "Pencak Silat Talent Test Development," International Journal of Human Movement and Sports Sciences, Vol. 8, No. 6, pp. 361 - 368, 2020. DOI: 10.13189/saj.2020.080607.

(b): Rony Syaifullah, Rumi Iqbal Doewes (2020). Pencak Silat Talent Test Development. International Journal of Human Movement and Sports Sciences, 8(6), 361 - 368. DOI: 10.13189/saj.2020.080607.

Copyright $\bigcirc 2020$ by authors, all rights reserved. Authors agree that this article remains permanently open access under the terms of the Creative Commons Attribution License 4.0 International License

\begin{abstract}
High achievement was determined by many factors, one of which is athlete's talent. A child's talent identification program needs to be carried out before carrying out achievement-oriented training process. The research purpose was to produce anthropometric, physiological and biomotor measurement indicators to identify the talented athletes in the pencak silat sport category of 12-14 years old. The research used development research by referring to the Borg and Gall's development stages. The stages begin from the need analysis, instrument preparation, testing and application in group trials. The development of talent tests includes 15 test series consisting of 5 anthropometric tests, 5 physiological tests and 5 biomotor tests. The results of validity and reliability tests on 15 test items produced high category validly and reliably. So it can be concluded that (1) The guiding model of pencak silat talent named "RS Silat Talent Test" can be used in displaying or identifying pencak silat talents as an operational step of implementing certain strategies in guiding pencak silat talent; (2) The guiding model of pencak silat talent contains fifteen units of test items.
\end{abstract}

Keywords Development, Talent Test, Pencak Silat

\section{Introduction}

\subsection{Background}

Regulation must achieve the target through the appropriate regulatory attribute features and the quality of players, coaches, and related staff in the sports sector
(Nadikattu \& States, n.d.). Many sports problems required every policy maker, institution and sports organization must improve the system and quality of coaching so that it can make a better contribution to the Indonesian sports. Various improvements have been made by the Indonesian government in improving sport achievements, including the implementation of national training camps such as the Garuda Emas, Program Atlet Andalan and Program Indonesia Emas. The government efforts have had an impact on the desired improvement, but not everything expected can be answered, because various other problems arise, such as unsustainable guidance pattern from an early age, adolescents to adulthood.

A very fundamental problem is the recruitment of athletes in Indonesia only based on the competition results. Another contributing factor is the limitations or lack of a talent scouting model for each sport. Talent scouting is someone whose job is to find people who have extraordinary abilities and recruit them to work professionally (Wazir, Torfs, Mostaert, Pion, \& Lenoir, 2017). The current talent test model is a general talent test model whose results recommend potential athletes be gifted in certain sports and it is an adaptation of talent tests from other countries.

Pencak silat is a general term that describes fighting and martial art (McPherson \& Pickett, 2010). Pencak silat is a sport that has mental, spiritual, martial arts, arts and sports aspects. Spiritual mentality is closely related to a noble personality, obedience to the norms and values that exist in religion and society, always uphold brotherhood, have a strong character and faith in God Almighty. Pencak Silat aspect related to the condition that required a fighter to defend himself when in a threatened condition or endangering himself. Art aspects shown that pencak silat is 
identical with taste, aesthetics and beauty in its movements. The sport aspect means that pencak silat is also one of the elements of sport that is contested and physical fitness and achievement purposes. Pencak Silat can be a physical activity that can improve health and fitness (Altavilla, D’elia, D’isanto, \& Manna, 2019).

The sport aspect is closely related to achievement, this required the pencak silat organization to conduct intensive coaching so that maximum achievement can be achieved. The program and management of the pencak silat training center have not demonstrated harmonious synergy. This causes the performance of pencak silat arts into ups and downs. The failure of the pencak silat, especially the competition category, has been felt since the 2003Vietnam Sea Games. While in the world championship, Indonesian pencak silat achievements began to decline since 2002. Indonesian pencak silat still triumphed in the singles, doubles and squads until now, while in the match number has decreased.

In a system of achievement sports fostering, the athlete recruitment system is an important step to guarantee the achievement of sustainable achievement. Recruitment system consists of stages of selection and determination of prospective athletes who meet all the requirements and criteria that have been determined. The main criterion is the giftedness or talent factor, by knowing the talent of the prospective athlete, the process of fostering achievement becomes clear, besides that further coaching (talent development) becomes more effective and efficient than fostering the unknown potential athletes. The selection or identification process of talent is carried out at the ideal age of the child to start training. Sports talent identification is the process of giving characteristics to the basic abilities brought from birth that can underlie sports skills. In this regard, the instrument for identifying talented athletes is important to be held.

\subsection{Research Purposes}

The research purpose was produced anthropometric, physiological and biomotor measurement indicators to identify the talented athletes in the pencak silat category of 12-14 years old.

\section{Methodology}

\subsection{Research Place and Time}

The study was conducted in Central Java Province for 1 year.

\subsection{Research Methods}

The research was used the Borg and Gall's Research and Development method by carrying out 7 stages. Research and development was used to produce certain products and test product effectiveness.

\subsection{Research Samples}

The research samples are athletes aged 12-14 years old selected by purposive sampling technique. The determination of the 12-14-year age sample is related to $\mathrm{PB}$ IPSI regulations in the type of age group contested. Sample criteria include being willing to be a sample, active in physical education activities and joining a pencak silat college in Central Java Province, and having participated in pencak silat training for a minimum of 2 years.

\subsection{Research and Development Stages}

The development stage was used Borg and Gall's development on book of Planning and Developing Advisory Programs for the Personalization of Education: A Handbook to Guide School Leaders of Large High Schools in Kansas. The development research stages include: 1) Review and literature analysis; 2) Need assessment; 3) product development; 4) Preliminary field test; 5) Initial revision; 6) Main field test; 7) Final product revision.

The explanation of stages of Borg and Gall (Gall, Borg, \& Gall, 2007) development research is as follows:

1. Review and literature analysis

The researcher conducts an initial study a literature review. Literature review shown that the guiding model of pencak silat talent is part of the development of pencak silat that cannot be ignored.

2. Need assessment

At this stage, the researcher conducts need analysis which is carried out by field observations.

3. Product development

Researchers plan models to solve existing problems in the field about the pencak silat athletes' talent. Researchers develop a guiding test model for pencak silat talent.

4. Preliminary field test

At this stage the product developed is validated. Validation is done by discussion with pencak silat coaching experts.

5. Initial revision

At this stage is carried out revision of developed product. Revisions are made according to expert input.

6. Main field test

At this stage, researchers conduct a small group trial or a limited group of respondents as product users and conduct a large group trial as a product user respondent

7. Final product revision

This stage the researchers revise the product development based on input from small group trial and large group tests. 


\subsection{Data Collection}

Data collection was done by tests. Test is a way to make an assessment in the form of a task or series of tasks that must be done by a person or group to produce a value about the behavior or achievement of the child. The test objectives are (1) determine the participant status, the progress he/she made, or the level of ability possessed so that the participant can be grouped according to his ability, (2) motivate the participant to be able to practice harder, both inside and outside the training schedule, (3) evaluate the effectiveness of programs, methods and contents (Kirkendall, 1987). Tests conducted in this research include anthropometric, physiological, and biomotor tests. Anthropometric measurements, physical and biomotoric abilities are useful in planning the implementation of exercise programs and differentiating athletes according to their talents (Wazir et al., 2019).

\subsection{Research Instrument}

1. Body High Test

Using a roll meter. This tool measures the length of the body when standing upright from the floor to the tip of the head. This tool produces a height figure within $0.5 \mathrm{~cm}$

\section{Body Weight Test}

Using a scale. This tool measures the weight of the entire body not wearing footwear/shoes.

\section{Hand span test}

Using roll meter. This test measures the horizontal span between the tips of the middle fingers stretched sideways at shoulder height.

\section{Sitting high test}

Using roll meter. This test measures the vertical distance from the base of the seat surface to the top (vertex) of the head.

\section{Leg length}

Using roll meter. This test measures the vertical distance between the trochanterion and the sole of the foot.

\section{Muscle strength Test}

Done with push-ups that use a stopwatch to measure time. This test measures the ability of the muscles to make a maximum contraction against resistance or load.

\section{Flexibility test}

This test measures the quality of a moving body segment with maximum range of joints.

\section{Coordination test}

This test measures the ability to make movements or work precisely and efficiently.

\section{Aerobic and anaerobic capacity tests}

This test measures a person's maximum capacity without experiencing fatigue.

\section{Speed test}

This test measures the ability to move from one to another place in the shortest possible time.

\section{Agility test}

This test measures the ability to change body direction or position quickly which is carried out together with other movements

\section{Power/explosive test}

This test is a combination of strength and speed or mobilization of maximum muscle force with maximum speed.

\subsection{Data Analysis}

Data analysis was performed using validity test with correlation with criterion technique and reliability test used Chronbach alpha formula. The instrument validity is valid if the correlation coefficient $t_{\text {count }}>t_{\text {table }}$

\section{Results}

\subsection{Identification and Need Analysis}

This stage was carried out with field observations and discussions of experts involved in the process of building pencak silat sports. The result of field observations that there is a problem in the implementation of pencak silat talent scouting, namely the scouting model of pencak silat talent has not been carried out systematically and has not used standardized instruments and still uses general methods. The results of the experts' discussion include:

1. Need to prepare a system for managing and implementing the measurement of pencak silat talent tests.

2. Preparing the easy and practical instrument.

3. Solution by developing guiding model of pencak silat talent that can produce prospective high-quality pencak silat athletes.

4. Identifying the factors that influence the trial of development model of pencak silat talent scouting such as anthropometry, physiology and biomotor.

\subsection{Scouting Model of Pencak Silat Talent}

The scouting model designed is in the form of software. This model was used as a means of identifying or recruiting talented athletes. This software contains 19 test instruments relating to the selection of pencak silat talents athletes based on anthropometric and physical domains. The 19 pencak silat talent test instruments in software include tests for height, sitting height, weight, arms span, leg length, push-ups, sit-ups, back-ups, basketball throwing, three 
hops, shuttle run $3 \mathrm{~m}, 20 \mathrm{~m}$ run, multistage fitness test, hand ankle coordination, flexibility, 30-second punches, 30-second front kicks, 30-second sickle kicks, 30-second side kicks.

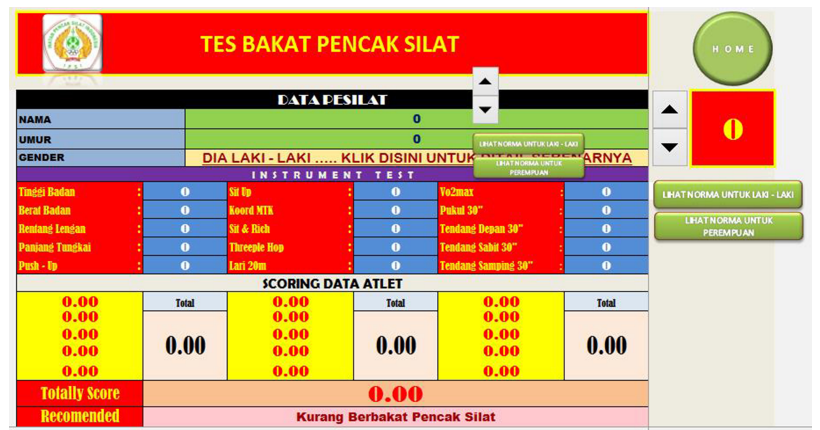

Figure 1. Display of pencak silat talent scouting software

\subsection{Limited Trial (Small Group)}

The trial was conducted with a sample of 126 students (55 male and 71 female). The sample takes data with the prepared talent scouting model. In limited trial, the researcher together with two observers made observations the implementation of the test and measurement using a model of pencak silat talent scouting. The measurement results in the trial sample are limited with 19 developed test instruments, then performed the validity and reliability tests.

\subsection{Validity Test}

Table 1. Validity test results

\begin{tabular}{ccccc}
\hline Item Tes & rcount & rtable & tcount & ttable \\
\hline Height & 0,31 & 0,17 & 3,63 & 1,98 \\
Seated Height & 0,14 & 0,17 & 1,00 & 1,98 \\
Weight & 0,35 & 0,17 & 4,10 & 1,98 \\
Arms Range & 0,61 & 0,17 & 8,48 & 1,98 \\
Leg Length & 0,30 & 0,17 & 3,52 & 1,98 \\
Push-Up & 0,22 & 0,17 & 2,51 & 1,98 \\
Sit-Up & 0,71 & 0,17 & 11,38 & 1,98 \\
Back-Up & 0,10 & 0,17 & 1,34 & 1,98 \\
Coordination & 0,66 & 0,17 & 9,74 & 1,98 \\
Sit \& Reach & 0,58 & 0,17 & 7,94 & 1,98 \\
Basket ball throw & 0,10 & 0,17 & 1,33 & 1,98 \\
3 Hop & 0,58 & 0,17 & 7,98 & 1,98 \\
Shuttle Run & 0,16 & 0,17 & 1,34 & 1,98 \\
20 m run & 0,66 & 0,17 & 9,69 & 1,98 \\
VO2max & 0,59 & 0,17 & 8,11 & 1,98 \\
Blow & 0,25 & 0,17 & 2,92 & 1,98 \\
Front kick & 0,29 & 0,17 & 3,35 & 1,98 \\
Sickle kick & 0,18 & 0,17 & 2,05 & 1,98 \\
Sickle kick & 0,22 & 0,17 & 2,54 & 1,98 \\
\hline & & & &
\end{tabular}

Table 1 shows the results of the validity tests result. $T_{\text {count }}>t_{\text {table }}$ it can be concluded that the test developed valid. There are 4 invalid test instruments, so 4 test instruments are not included in the talent scouting software.

\subsection{Reliability Test}

Table 2. Reliability test result

\begin{tabular}{|c|c|c|}
\hline No. Question & Varians & Varians $^{2}$ \\
\hline 1 & 100 & 10000 \\
\hline 2 & 100 & 10000 \\
\hline 3 & 100 & 10000 \\
\hline 4 & 100 & 10000 \\
\hline 5 & 100 & 10000 \\
\hline 6 & 100 & 10000 \\
\hline 7 & 100 & 10000 \\
\hline 8 & 100 & 10000 \\
\hline 9 & 100 & 10000 \\
\hline 10 & 100 & 10000 \\
\hline 11 & 100 & 10000 \\
\hline 12 & 100 & 10000 \\
\hline 13 & 100 & 10000 \\
\hline 14 & 100 & 10000 \\
\hline 15 & 100 & 10000 \\
\hline Total & 1500 & 150000 \\
\hline
\end{tabular}

Table 2 shows the variance value of each question which is then included in the calculation of reliability and the results is compared based on the Guiford classification

$$
\begin{gathered}
r_{x y}=\left[\frac{k}{k-1}\right]\left[1-\frac{\sum \sigma_{b}^{2}}{\sigma_{t}^{2}}\right] \\
r_{x y}=\left[\frac{15}{15-1}\right]\left[1-\frac{1500}{4913.51}\right] \\
r_{x y}=0.74
\end{gathered}
$$

Table 3. Guiford's Classification

\begin{tabular}{cc}
\hline r-value & Category \\
\hline$<0.02$ & No correlation \\
$0.02-0.39$ & Low correlation \\
$0.40-0.69$ & Medium correlation \\
$0.70-0.89$ & High correlation \\
$0.90-0.99$ & Very high correlation \\
1.00 & Perfect correlation \\
\hline
\end{tabular}

The reliability calculation used the alpha formula yields a r-value 0.74. Based on the Guiford's classification, the reliability of the pencak silat talent scouting tests was included in the high category. 
Based on the validity and reliability tests produced 15 valid and reliable test instruments that can be used to identify the talented athletes in the pencak silat. The 15 test instruments include height, weight, arms span, leg length, push-ups, sit-ups, eye ankle coordination, sit \& reach (flexibility), 3 hops, 20-meter running, multistage fitness test $\left(\mathrm{VO}_{2} \mathrm{max}\right), 30$ second punch, 30 second front kick, 30 second sickle/bow kick, and 30 second side kick.

\subsection{Broad Trial (Large Group)}

Broad trials or large groups are carried out with a sample of 8 regions in Central Java Province that have pencak silat training. The 8 regions that were sampled included Kebumen 24 athletes (12 male, 12 female), Magelang 37 athletes (18 male, 19 female), Banyumas 51 athlete (32 male, 19 female), Kebumen 22 athlete (10 male, 12 female) , Klaten 21 athletes (10 male, 11 female), Pati 21 athlete (11 male, 10 female), Semarang 30 athlete (16 male, 14 female), Surakarta 40 athlete (17 male, 23 female). So that the total sample in a broad trial is 246 athletes.

In broad trials, discussions were held again with experts. The results of the discussion include:

\section{Weighting on each test item}

The test items weighting are as follows; $3 \%$ height, 3\% body weight, $3 \%$ arm span, $3 \%$ leg length, $6 \%$ push-up, $6 \%$ sit-up, $6 \%$ ankle coordination, $6 \%$ flexibility, $6 \%$ three hop, $8 \%$ run $20 \mathrm{~m}$ and $10 \%$ multistage fitness test, $10 \% 30$ seconds stroke, $10 \%$ front kick 30 seconds, $10 \%$ sickle/bow 30 seconds and $10 \%$ side kick 30 seconds.
2. Determination of the three norm scales, namely talented (B), quite talented (CB), and less talented (KB)

3. There are equalized units of scores $3,2,1$

Table 4. Results of Broad Trial of Talent Scouting

\begin{tabular}{cccc}
\hline Group & Criteria & Total & \% \\
\hline Male & Talented & 11 & $9 \%$ \\
& Quite talented & 106 & $84 \%$ \\
\multirow{3}{*}{ Female } & Less talented & 9 & $7 \%$ \\
& Talented & 9 & $8 \%$ \\
& Quite talented & 105 & $88 \%$ \\
& Less talented & 6 & $5 \%$ \\
\hline
\end{tabular}

Table 4 shows that results of talent scouting in 246 pencak silat athletes. In male athletes there are 11 talented athletes, 106 quite talented athletes, and 9 less talented athletes. In female there are 9 talented athletes, 105 quite talented athletes, and 6 less talented athletes.

\subsection{Instrument Scoring}

Table 5. Norms of Pencak Silat Talent Test

\begin{tabular}{ccc}
\hline Score & $\begin{array}{c}\text { Score } \\
\text { Category }\end{array}$ & Category \\
\hline$\geq 3.6$ & 3 & Talented \\
$1.6-3.5$ & 2 & Quite talented \\
$\leq 1.5$ & 1 & Less talented \\
\hline
\end{tabular}




\subsection{Software Manual Instructions}

1. Install the software and read the instructions or guides

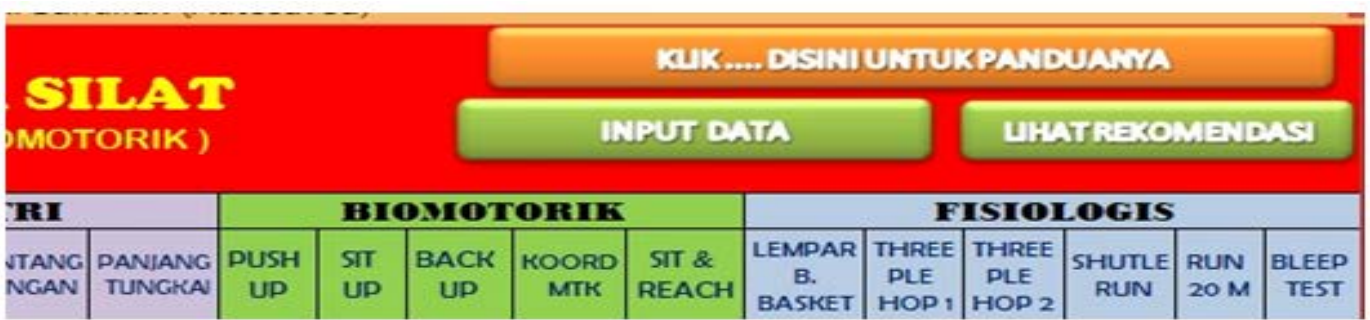

Figure 2. Display of Software Guide

2. Input data

\section{INPUT DATA}

Figure 3. Data Input Button

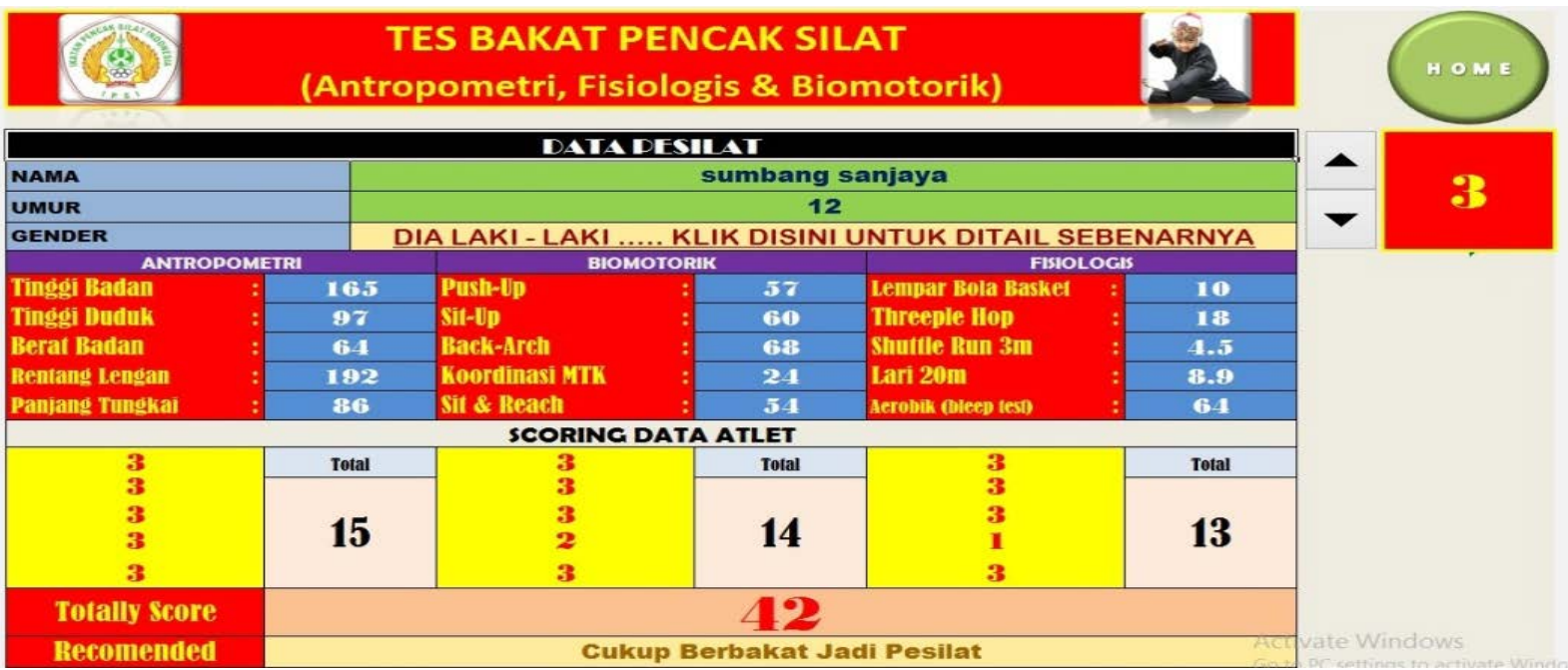

Figure 4. Display of Input data

3. After inputting the data, click the recommendation button and a talent recommendation will appear

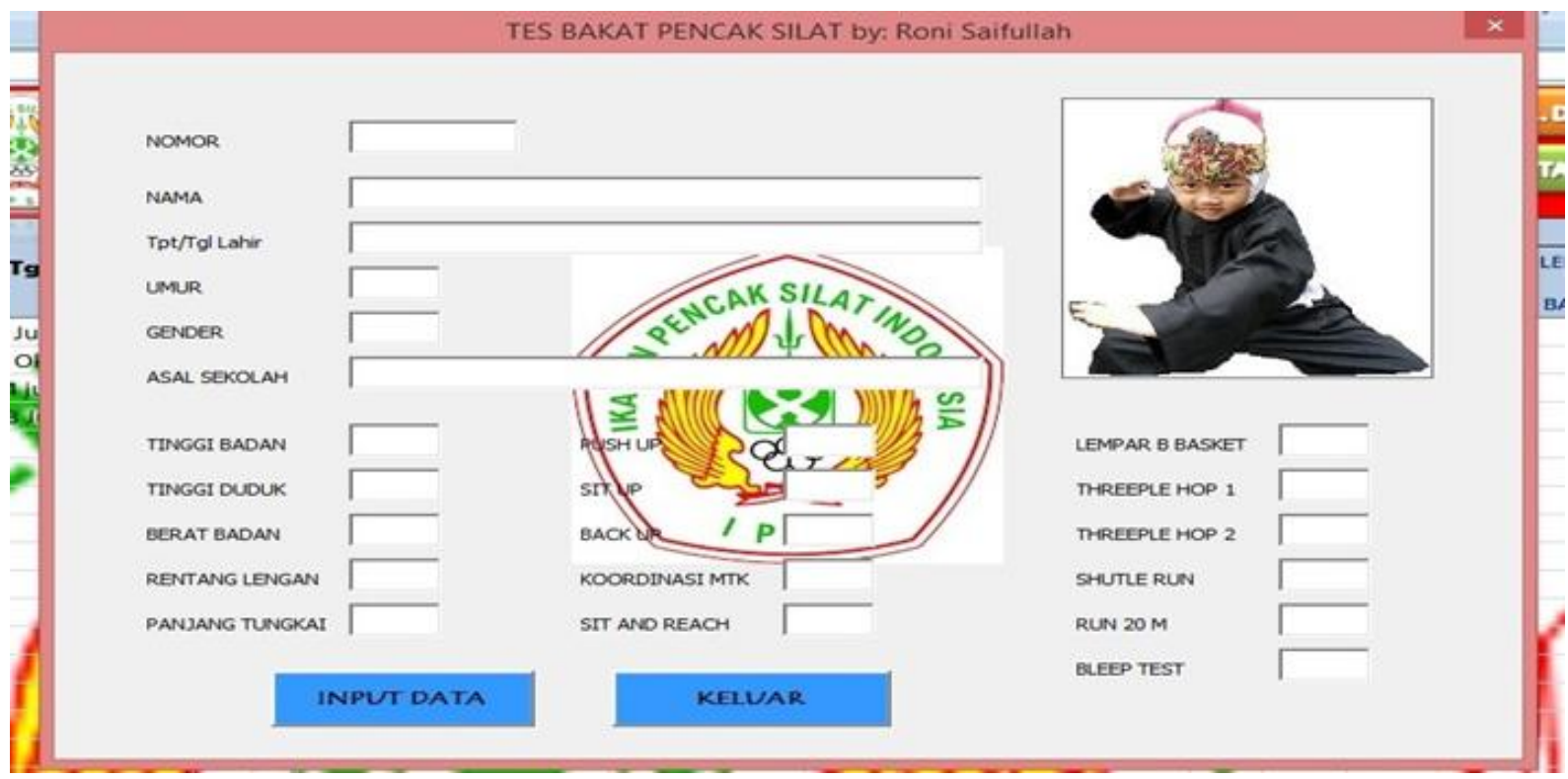

Figure 5. Display of Talent Recommendation 
4. To find the wanted data, click the arrow next to the number column

5. To finish, click home button

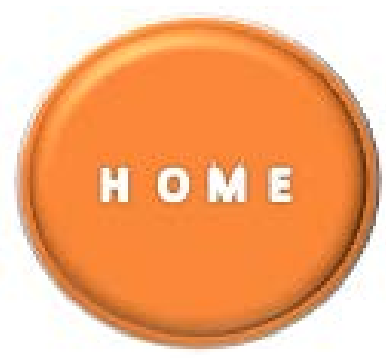

Figure 6. Home button

\section{Discussion}

All movements in pencak silat depend on muscle contraction, so it involves two main factors, namely: 1 ) The energy source needed by muscles to contract (will involve checking the energy system); 2) The quality of muscle contractions that are considered to represent muscle strength. Both factors must be considered to fully understand the physiological basis of training. The results of the observational analysis showed that the pencak silat energy system was ATP-PC = 90 - 95\%; LA = 5-10\%; and $\mathrm{O} 2=0 \%$, thus the development of energy systems leads to anaerobes. In line with these results, a fighter is required to develop physical components, including: anaerobic capacity, power, muscle capacity, muscle strength, agility, speed, reaction speed, flexibility and coordination. A player's cognitive abilities and performance will affect the general physical condition (Meeusen, 2014). Special physical abilities of pencak silat include performance of pencak silat skills, speed of pencak silat kicks, agility of pencak silat kicks, coordination of pencak silat kicks and power of pencak silat kick.

High achievement is determined by many factors, including the quality of the trainer, the quality of the training program, equipment and supporting facilities, support from the government, sponsors and parents, and athlete talent. An early childhood talent identification program is needed before carrying out a training process oriented to achieving high achievement. The process of talent identifying was carried out to determine the potential child in one sport, in accordance with the talent possessed. The fact is, many children pursue one sport not based on identifying talent. Talent in sports was based on social, physiological, psychological and physical indicators (Pereira, Dias, Lima, \& Coto, 2020). Pencak silat talent is a special ability that can be seen from certain components that must be possessed by pencak silat athletes in order to achieve maximum performance. Pencak silat talented athletes are those who have special characteristics to be able to develop to support the successful achievement in the pencak silat.

The guiding model of pencak silat talent is as a process, series or sequence of changes, in bringing up or identifying pencak silat talents as an operational step of implementing certain strategies in guiding pencak silat talent. The purpose of guiding pencak silat talent scout emphasizes on identifying the giftedness of pencak silat by referring to the suitability of the potentials and interests of athletes and aims to predict with a high probability of how much a person's chance of successfully achieving maximum achievement in the pencak silat. Availability or absence of human resources to choose talent is an important factor in the model and development of talent identification (Krasilshchikov, 2015).

There are 15 test items in the Sport Search modification. Administration of all test items in a session duration of 95 minutes is allowed to be carried out with a comparison between the testi and tester of 10: 1 . Need to arrange the order of test items in two or more parts. If grouped into two parts, then you should use five testers. Each tester should handle the testing and testy post should do from one post to another post. The recommended sequence of tests is the first part, including height, weight, arms span and leg lengths; then the second part, covering the push-up test, sit-ups, eye ankle coordination, sit-and-reach then the third part, three hops, $20 \mathrm{~m}$ run, $\mathrm{VO}_{2 \max }$ with MFT, 30 seconds punch, 30 seconds front kick, Sickle/bow 30 seconds and side kick 30 seconds. It should be noted that the MFT test $\left(\mathrm{VO}_{2 \max }\right)$ is done last in the third part.

The research results support previous research which observed that this study aimed at identifying talent in 15 countries with an analysis of 12 success factors. This program is concerned with national strategies that lead to the identification of talented young athletes. The results of the study concluded that the research findings were related to the role of sports clubs. The research results can be used for managing talent development at sports clubs, national sports associations and coach education (De Bosscher \& De Rycke, 2017). In other previous studies related to talent identification tests for wrestling achievement with a sample of 165 trainers. The results showed 106 (64.24\%) were detected in talent tests in athletes who had just started wrestling and 59 (35.75\%) were not detected in talent tests. 41 (38.68\%) trainers applied talent tests to wrestlers based on their assessment of basic wrestling motoric characteristics, 36 (33.96\%) physical structure and wrestler athlete tendencies, 19 (17.92\%) on competition observation and technical characteristics and 10 (9.43\%) on intelligence. Wrestling coach talent identification tests can be effectively applied to athletes in identifying potential athletes (Kaynar, 2019).

The research results can be compared with other research on instrument development research. New video coding-based instrument for individual game performance assessments of children aged 11-12 years on handball and football games. The research conclusion is the instrument 
developed providing a valid and reliable method for authentic assessment of individual decision-making during play (Isabel, et al., 2007).

\section{Conclusions}

1. The guiding model of pencak silat talent named "RS Silat Talent Test" can be used in displaying or identifying pencak silat talents as an operational step of implementing certain strategies in guiding pencak silat talent.

2. The guiding model of pencak silat talent contains fifteen test items.

\section{REFERENCES}

[1] Altavilla G,DF,DT,\&MA. Tests for the evaluation of the improvement of physical fitness and health at the secondary school. Journal of Physical Education and Sport. 2019; 19(5): p. $1784-1787$.

[2] A.Pribadi. B. Model desain Sistem Penelitian. Jakarta: Dian Rakyat. 2009.

[3] De Bosscher V,\&DRJ. Talent development programmes: a retrospective analysis of the age and support services for talented athletes in 15 nations. European Sport Management Quarterly. 2017; 17(5): p. 590-609.

[4] Djoko Pekik Irianto d. Materi Pelatihan Kondisi Fisik Dasar, Jakarta: Asdep Pengembangan Tenaga dan Pembina Keolahragaan, Kemenpora. 2009.

[5] Doug MacCurdy. Talent Identification Around The World. 2013 January 2.

[6] Gall, M., Borg, W., \& Gall, J. Educational research: An introduction $\left(6^{\text {th }}\right.$ education). White Plains, New York: Longman Publishers USA. 2007.

[7] Isabel Tallir EM. Kristof Lannoo dan Joeri Van de Voorde Validation of video-based instruments for the assessment of game performance in handball and soccer. Belgia: Ghent
University. 2007.

[8] James Tangkudung KO. Pembinaan Prestasi Olahraga Jakarta :Cerdas jaya. 2006.

[9] Kaynar Ö. Investigation of the effects of the talent identification tests used by the coaches in wrestling on success. Universal Journal of Educational Research. 2019; 7(3): p. 885-891.

[10] L. K. Gustafson dan Robert Maribe Branch, Survey of Instructional Development Models. New York: ERIC Clearinghouse on Information \& Technology. 2002.

[11] Krasilshchikov O. Talent Identification and Development : Reassessing the Talent Identification and Development. 2015 April.

[12] McPherson M,\&PW. Characteristics of martial art injuries in a defined Canadian population: A descriptive epidemiological study. BMC Public Health. 2010;: p. 10.

[13] Meeusen R. Exercise, nutrition and the brain. Sports Medicine. 2014; 44(SUPPL.1): p. (SUPPL.1.

[14] Nadikattu RR,\&SU(d). IMPLEMENTATION OF NEW WAYS. ; 14(1001): p. 5983-5997.

[15] Pereira MM,DRBeLMR,\&CNP. Use of Panoramic Dental Radiography for Talent Identification and Development in Youth Soccer: A Pilot Case. International Journal of Odontostomatology. 2020; 14(2): p. 141-143.

[16] Reilly T WANAFA. A multidisciplinary approach to talent identification in soccer. Liverpool: John Moores University Research Institute for Sport and Exercise Sciences. Journal Sports Sci. 2000 September 18.

[17] Romann M. Innate Talent Is Adaptable - Comment on Baker \& Wattie. Current Issues in Sport Science. 2019; 4.

[18] Wazir MRWN,HMVMM,DFJA,PJ,\&LM. Identification of elite performance characteristics in a small sample of taekwondo athletes. PLoS ONE. 2019; 14(5): p. 1-12.

[19] Utami Munandar ea. Anak-anak Berbakat Pembinaan dan Pendidikannya. Jakarta: CV Rajawali. 1982.

[20] Wazir MRWN,TM,MM,PJ,\&LM. Predicting judo champions and medallists using statistical modelling. Archives of Budo. 2017; 13: p. 161-168. 